\title{
Industrial characteristics and consumer properties of Chaenomeles Lindl. fruits
}

\author{
Y. V. Lykholat ${ }^{1}$, N. O. Khromykh', T. Y. Lykholat ${ }^{1}$, O. O. Didur ${ }^{1 *}$, O. A. Lykholat ${ }^{2}$, T. V. Legostaeva', \\ A. M. Kabar' ${ }^{1}$, T. V. Sklyar', V. M. Savosko ${ }^{3}$, I. M. Kovalenko ${ }^{4}$, V. R. Davydov' ${ }^{1}$, Yu. V. Bielyk ${ }^{1}$, K. O. \\ Volyanik' ${ }^{1}$, A. V. Onopa' ${ }^{1}$, K. A. Dudkina', I. P. Grygoryuk ${ }^{5}$
}

'Oles Honchar Dnipro National University, Gagarin av., 72, Dnipro, Ukraine, 49010

${ }^{2}$ University of Customs and Finance, Volodymyr Vernadsky St. 2/4, Dnipro, Ukraine, 49000

${ }^{3}$ Kryvyi Rih State Pedagogical University, Gagarin av., 54, Kryvyi Rih, Ukraine, 50000

${ }^{4}$ Sumy' National Agricultural University, Kondratyeva Str., 160/5, Sumy, 40021

${ }^{5}$ National University of Life and Environmental Sciences of Ukraine

Geroiv Oborony Str., 13, Kyiv, Ukraine, 03041

*Corresponding author e-mail: didur@ua.fm

\begin{abstract}
The comparative analysis of the fruit and seed capacity of Chaenomeles Lindl., grew in the botanical garden of the Oles Honchar Dnipro National University, was carried out. It is shown that all studied taxa undergo a complete vegetation cycle. According to our observations, the duration of the growing season is as follows: the smallest in Chaenomeles japonica, the longest in $C$. $x$ superba and C. maulei, the longest in C. speciosa, C. cathayensis and C. californica. Seed length in Chaenomeles plants ranged from $4.2 \pm 0.10 \mathrm{~mm}$ ( $C$. japonica var. maulei) to $8.5 \pm 0.25 \mathrm{~mm}$ ( $C$. cathayensis). Seed widths varied from $4.1 \pm 0.32 \mathrm{~mm}(C$. cathayensis) to $11.1 \pm 0.10 \mathrm{~mm}$ ( $C$. japonica var. maulei). According to the results obtained, the average number of seeds in one fruit of different Chaenomeles species differed, decreasing in the following order: $C$. cathayensis, $C$. speciosa $>C$. $\times$ californica $>C$. $\times$ superba $>C$. japonica $>C$. japonica var. maulei. Most of the Chaenomeles genus representatives were found to be in a good condition: $C$. japonica var. maulei vitality was estimated at 7 balls, $C$. japonica and $C$. $\times$ superba -6 balls. This index is slightly lower for C. speciosa, C. $\times$ californica and C. cathayensis as 5 and 4 balls, respectively. It should be noted that the highest vitality was shown by C. japonica var. maulei, which was introduced in the Botanical Garden of DNU in 1955. In research, considerable attention has been paid to the antioxidant system, which is a powerful mechanism preventing the development of avalanche-free and radical peroxide reactions in living organisms. The antioxidant capacity of Chaenomeles fruits, determined in the range from $565.8 \pm 15.7$ ( $C$. speciosa) to $1121.7 \pm 27.5$ ( $C$. cathayensis) mg UAE / $100 \mathrm{~g}$ DW, can be considered quite high. The overall antioxidant capacity was highest for $C$. cathayensis fruits (1121.7 $\pm 27.5 \mathrm{mg} \mathrm{AE} \mathrm{/} 100 \mathrm{~g}$ DW), which exceeded the indexes of other species by 1.2-2.0 times. The presence of antioxidants in raw materials and finished products provides for the prevention of their deterioration, reduction of losses, increase the shelf life and release of high quality products, retaining for a long time the characteristic features inherent in fresh, complete products. High taste qualities are characteristic of $C$. speciosa and $C$. $\times$ californica. Considering the large assortment of Chaenomeles, representatives differing in their biological, physiological and nutritional properties, we consider it promising to introduce their use in the food industry to obtain functional products with high consumer properties, namely, high content of antioxidants, catering for a variety of dishes or for exotic flavors, as well for direct consumption by the population of useful fruits with different flavors.
\end{abstract}

Keywords. representatives of Chaenomeles; phenological phases; fruit characterictic; seminal ability; antioxidant system; estimation of taste quality; perspective species

\section{Introduction}

The environmental effects of different nature xenobiotics and arid climate in the Steppe Dnieper negatively influence on all elements of ecosystems: soil, in particular, devastated (Savosko, 2011; Savosko et al., 2018), plant metabolism (Myitsyik \& Lykholat, 2000; Grygoryuk et al., 2014; Lykholat et al., 2017, 2018; Opanasenko et al., 1998) and animal organisms (Andrusevich et al, 2018; Lykholat et al., 2016, 2018, 2019; +Marenkov et al., 2019; Pokhylenko et al., 2019), which as result has a adversely impact on health population (Pertseva et al., 2007, 2008; Yermishev et al., 2017). 
Now there is evidence that environmental changes in recent decades have proven to be favorable for some adventitious species and have allowed them to spread to regions where they previously had no chance of survival and reproduction. Longstanding studies conducted simultaneously in different countries (Berger et al., 2007; Baranovski et al., 2016) have confirmed that the last several decades milder winter conditions are consistent with the trend of south-to-north expansion of potential introduced plant ranges, a likely consequence of a significant change in the composition and structure of natural and artificial plantations in different parts of Europe.

In the Dnipropetrovsk region, the adventitious shrubs, a considerable part of which belongs to the low-spread nontraditional fruit species, show high resistance. In this regard, considerable attention should be paid to the research of this particular plant group, in which fruits, leaves, stems and other parts have high biological value and ones are a source of physiologically active compounds that can be used as a raw material for the food industry, the prevention and treatment of many diseases (Baranovski et al., 2016).

Wide use of the introduced nonconventional rare fruit spesies allows to expand a variety of specific structure of regional flora and at the same time creates a possibility of expansion of the vegetable raw materials range for satisfaction of req uirements of the industry, medicine and food of the population. In Ukrainian conditions more than 400 fruit and berry plants species are grown up whereas in the conditions of Dnepropetrovshchina their number is much less. The significant effect on taxons distribution is carried out by adverse regional climatic conditions: low air temperatures in the winter and high in the summer, insufficient amount of moisture in the soil, frequent hot dry winds, etc.

In these conditions increasing vital of a vegetable organism is promoted, in particular, by use of synthetic regulators of plant growth (Shcherbyna et al., 2017).

Among rare fruit plants industrial value are deserved by representatives of the sort Chaenomeles in the conditions of Dnieper steppe. These plants, in general, is rather unpretentious to environmental conditions, rather easily transfer severe winter and successfully grow on any types of soils.

For prevention of diseases by increase in stability of the immune system of a human body it is possible to use fruits of representatives of the sort Chaenomeles of which it is characteristic the high content of vitamins and phenolic connections. It is known that Chaenomeles fruits are rich on ascorbic acids (50-200 mg / 100 g), pectins (1-3\%), have low contents sugars (2$5 \%$ ), and behind the vitamins content exceed lemons (Mezhens'kij, 2004; Homich of et al., 2014). Existence in fruits of considerable content of cellulose (2-4 \%) testifies to a possibility of fruits use at low-calorie food production. If lemon can be grown up only in the closed soil trees in the conditions of the steppe of Ukraine, then plants of Chaenomeles are capable to transfer climatic features of this zone.

Experimentally confirmed the high content of L-ascorbic acid and phenolic connections of fruits Chaenomeles proves their high biological value, as polyphenols are powerful antioxidants that are capable to protect a vegetable organism from negative impact of environment factors by neutralization of free radicals (Homich et al., 2014).

Distribution of any species in the region depends, first of all, on its ability to breed in the seed and vegetative way. At the same time, the regeneration ability of the introduced plants in new conditions of growth is of particular importance. Botanical garden of DNU by Oles Honchar located in Dnieper steppe zone is one of the centers of plants introduction in Ukraine.

In this regard, we have conducted researches of industrial characteristics and tastes of the sort Chaenomeles representatives introduced in DNU by Oles Honchar botanical garden conditions.

\section{Methods}

The studied samples of plants were selected in the territory of Botanical garden of DNU by Oles Honchar during 2017-2019 yy. Research objects were sort Chaenomeles representatives from a collection of a botanical garden: $C$. speciosa (Sweet) Nakai; C. cathayensis (Hemsl.) Schneider; C. japonica (Thunb.) Lindl.; C. japonica var. maulei; $C$. $\times$ superba (Frahm) Rehder; C. $\times$ californica Clarke ex Weber. The place of continuous growth of the sort Chaenomeles, representatives introduced in Botanical garden of DNU is presented in Table 1.

Table 1. Place of continuous growth and year of an introduction of the sorts Chaenomeles representatives growing in Botanical garden of DNU

\begin{tabular}{llc}
\hline \multicolumn{1}{c}{ Species } & Habitat & Introduction time \\
\hline C. speciosa & Moldova, Kishinev & 1996 \\
C. cathayensis & Moldova, Kishinev & 1996 \\
C. japonica & Moldova, Kishinev & 1996 \\
C. japonica var. maulei & Tajikistan, Khorog & 1955 \\
C. $\times$ superba & Moldova, Kishinev & 1996 \\
C. $\times$ californica & Crimea, Yalta, State Nykytsky botanical garden & 2006 \\
\hline
\end{tabular}

Phenological observations of the plants and industrial characteristic of seeds were carried out on standard by techniques (Kokhno \& Kurdyuk, 2010).

Level of vital of species can be considered as result of their success of an introduction. When carrying out a research vital taxons on the new place growth we carried out the state assessment for 8-ball scale (Savel'eva, 1975). 
Determination of tastes was carried out on a 5-ball scale which cornerstone tesis on the sour taste of fruits is caused, first of all, by the content of free acids connected with complex transformations of organic acids during plant development, with metabolism type in general and its dependence on environmental conditions (Serdyuk \& Stepanenko, 2015).

Antioxidant ability of Chaenomeles fruits was defined according to method by Pulido R. (Pulido et al., 2000). Antioxidant ability of the raw fruits extracts was expressed in an equivalent of ascorbic acid for of dried fruits (mg UAE / g DW) (Vinnychenko et al., 2014; Augustus et al., 2015).

Statistical processing of the results is carried out by means of Microsoft Statistica 6.0 package with the confidential probability of 95-99\%.

\section{Results and Discussions}

State assessment of species vital on the new place growth is relevant as on the basis of of these observations results scientific and practical recommendations on plant reproduction, cultivation and use in culture depending on origin of each concrete species and new growth conditions are developed. It is revealed that most of the sort Chaenomeles representatives is in proper condition. So, in $C$. japonica var. mauly vital level is estimated as 7 balls, $C$. japonica and $C$. $x$ superba as 6 balls. This indicator in C. speciosa, C. $\times$ californica and C. cathayensis, as 5 and 4 balls, respectively is slightly lower. It is necessary to notice that the highest vitality was shown by C. japonica var. Maulei introduced in DNU Botanical garden in 1955 (Table 2).

\section{Table 2}

Characteristics of Chaenomeles L. representatives growing in DNU Botanical garden

\begin{tabular}{lcc}
\multicolumn{1}{c}{ Species } & $\begin{array}{c}\text { State assessment by vital on the new place } \\
\text { growth }\end{array}$ & State assessment by taste \\
\hline C. speciosa & 5 & 5 \\
C. cathayensis & 4 & 2 \\
C. japonica & 6 & 4 \\
C. japonica var. Maulei & 7 & 3 \\
C. $\times$ superba & 6 & 4 \\
C. $\times$ californica & 5 & 5 \\
\hline
\end{tabular}

Upday, in the conditions of market production, in particular cultivation of fruit and berry cultures demands from using raw materials of high tastes which define demand, pricings and a financial position of producers. Tastes of fruits caused by the maintenance of such main components of the chemical composition as as sugars and organic acids, define prospects of their use for consumption of the population (Crisosto et al., 2004).

Depending on plant species a threshold feeling of sour taste of various sugars and acids unequal, and in the berries their content is changeable therefore precisely to calculate a point of taste compensation which is felt (a threshold of feelings), is hard. For different acids the feeling of sour taste (on $100 \mathrm{~mL}$ of solution) makes a threshold: lemon - 0,0154, apple - 0,0107, the guilty person - 0,0075. Sucrose begins to be felt at concentration of $0.38 \%$ (García-Mariño et al., 2008).

The most widespread scale of assessment of tastes is based that the sour taste of fruits is caused not by the general content of acids, but titred acidity, that is content of free acids. In the plant the different contents of separate organic acids are a consequence of distinctions in the ratio of speeds of enzymatic reactions which are the cornerstone of forming and transformations of their complex (Serdyuk \& Stepanenko, 2015).

On the basis of the researches it is established (see Table 2) that high tastes is characteristic for C. speciosa, C. $\times$ californica ( 5 balls), averages - for C. $\times$ superba, C. japonica (4 balls), satisfactory - for C. japonica var. Maulei and low - for $C$. cathayensis (2 balls).

On the basis of our phenological observations it is established what blooming of vegetative bloom es was observed in the following sequence: $C$. speciosa, C. $\times$ superba, C. Maulei, C. japonica, C. californica, C. cathayensis. More last blooming there was in Chaenomeles cathayensis and Chaenomeles maulei(Table 3).

Table 3. Phenological observations of Chaenomeles representatives

\begin{tabular}{lcccc}
\hline \multicolumn{1}{c}{ Species } & $\begin{array}{c}\text { The beginning of leaf } \\
\text { blosssoming }\end{array}$ & $\begin{array}{c}\text { Flowering } \\
\text { period }\end{array}$ & $\begin{array}{c}\text { Reaching period } \\
\text { fruits }\end{array}$ & $\begin{array}{c}\text { The beginning of leaf } \\
\text { fall (Julian date) }\end{array}$ \\
\hline C. speciosa & 18.03 & $25.03-19.04$ & $27.09-05.10$ & 03.11 \\
C. japonica & 20.03 & $27.03-10.04$ & $21.09-28.09$ & 01.11 \\
C. cathayensis & 21.03 & $29.03-13.04$ & $10.10-25.10$ & 05.11 \\
C. $\times$ superba & 19.03 & $29.03-14.04$ & $25.09-10.10$ & 02.11 \\
C. californica & 20.03 & $28.03-12.04$ & $25.09-10.10$ & 05.11 \\
C. japonicavar. maulei & 19.03 & $26.03-13.04$ & $14.09-01.10$ & 02.11 \\
\hline
\end{tabular}

Blossoming was started anew in C. speciosa, after all blossomed C. cathayensis and C. $\times$ superba. For C. speciosa was characteristic also long period of blossoming from 25.03 by 19.04 . 
Maturing of fruits began in Chaenomeles maulei and continued in the following order: Chaenomeles japonica, $C$. californica, $C$. $\times$ superba, $C$. speciosa. The beginning autumn coloring of leaves it was for the first time observed in $C$. japonica, then at $C$. Maulei, C. $\times$ superba, C. speciosa, C. californica and C. cathayensis.

In general, vegetation duration, according to our observations, following: the shortest in Chaenomeles japonica, longer in $C$. $x$ superba and C. maulei, the longest in C. speciosa, C. cathayensis та C. californica.

It is well known (Khromykh et al., 2018; Opanasenko et al., 2015) that the efficiency of plant introduction depends on the intensity of their seed reproduction. In turn, seed reproduction of introduced species depends on the degree of seed output from the fruit, its quality and similarity. The individual difference in fruiting and seed productivity of plants has a dual nature phenotypic and genotypic. Phenotypic changes are determined by meteorological conditions, which determine the difference in fruits and seed productivity by year. Genotypic factors are differences between individuals.

Based on this provision, we present below the results of a comparative analysis of the fertility and seed capacity of Chaenomeles plants (Table 4).

Table 4. Characteristics of fruits of Chaenomeles plants introduced in Dnipro Botanical Garden of Dnipro State University

\begin{tabular}{lccc}
\hline \multicolumn{1}{c}{ Species } & Seed length, $\mathrm{mm}$ & Seed width, $\mathrm{mm}$ & Number of seeds in one fruit, pcs \\
\hline C. speciosa & $5.2 \pm 0.15$ & $4.5 \pm 0.20$ & $90.3 \pm 0.42$ \\
C. cathayensis & $8.5 \pm 0.25$ & $4.1 \pm 0.32$ & $100.2 \pm 0.35$ \\
C. japonica & $6.25 \pm 0.16$ & $4.4 \pm 0.12$ & $74.6 \pm 0.35$ \\
C. japonica var. maulei & $4.2 \pm 0.10$ & $11.1 \pm 0.10$ & $54.5 \pm 0.35$ \\
C. $\times$ superba & $6.5 \pm 0.16$ & $4.2 \pm 0.11$ & $80.5 \pm 0.32$ \\
C. $\times$ californica & $6.4 \pm 0.25$ & $5.4 \pm 0.32$ & $84.3 \pm 0.32$ \\
\hline
\end{tabular}

Based on the study, it was found that the seed length of Chaenomeles plants varied from $4.2 \pm 0.10 \mathrm{~mm}$ ( $C$. japonica var. maulei) to $8.5 \pm 0.25 \mathrm{~mm}$ ( $C$. cathayensis). Seed widths varied from $4.1 \pm 0.32 \mathrm{~mm}$ ( $C$. cathayensis) to $11.1 \pm 0.10 \mathrm{~mm}(C$. japonica var. Maulei). The number of seeds in one fruit varied from $54.5 \pm 0.35$ ( $C$. japonica var. Maulei) to $100.2 \pm 0.35$ pcs ( $C$. cathayensis).

According to the results obtained, the average number of seeds in one fruit of different Chaenomeles species differed, decreasing in the following order: C. cathayensis, C. speciosa $>C$. $\times$ californica $>C$. $\times$ superba $>C$. japonica $>C$. japonica var. maulei

Fruit size is a specific parameter of a particular genotype, as well as important attributes of fruit quality that, along with other characteristics, help to properly evaluate new or introduced species (Kaldmae et al., 2013)

In research, considerable attention was paid to the study of the antioxidant system, which is a powerful mechanism preventing the development of avalanche-free radical and peroxide reactions in living organisms. Antioxidants are among the most important nutritional supplements that are natural or identical natural biologically active substances intended for direct ingestion or introduction into foodstuffs for the purpose of enriching the diet with individual nutritional or biologically active substances and their complexes. The antioxidants add into the raw materials and finished products ensures their prevention spoiling, reducing losses, increasing shelf life, and producing high-quality products retaining for a long time the characteristic features of fresh, complete products (Beltyukova et al., 2014).

The antioxidant system is represented by enzymatic antioxidants and low molecular weight components, among which the significant role is given to ascorbic acid determining the overall antioxidant capacity of both living organisms as a whole (Lykholat et al., 2016) and their individual components, such as fruit (Beltyukova et al., 2014). In the study of total antioxidant capacity level, the highest indices were characteristic of $C$. cathayensis fruits (1121.7 $\pm 27.5 \mathrm{mg}$ AE / $100 \mathrm{~g}$ DW), which exceeded other species indices by 1.2-2.0 times (Table 5).

Table 5. Overall antioxidant capacity of Chaenomeles fruits

\begin{tabular}{lc}
\hline \multicolumn{1}{c}{ Species } & Overall antioxidant capacity, mg Ascorbic Acid Equivalents / g DW \\
\hline C. speciosa & $565.8 \pm 15.7$ \\
C. cathayensis & $1121.7 \pm 27.5$ \\
C. japonica & $885.6 \pm 19.5$ \\
C. japonica var. maulei & $872.3 \pm 21.9$ \\
C. $\times$ superba & $784.8 \pm 16.8$ \\
C. $\times$ californica & $937.7 \pm 22.3$ \\
\hline
\end{tabular}

According to literature sources, the total antioxidant capacity of different species can vary over a large range, in particular, methanolic extracts of various Indian spices can vary from 0.57 to $6.0 \mathrm{mg}$ UAE / g DW (Deepa et al., 2013). A detailed study of the fruits of some members of the Solanaceae family showed that the antioxidant capacity was $48.8 \pm 0.6$ and $56.7 \pm 1.4 \mathrm{mg} \mathrm{AE}$ / g of dry extract (Nwanna et al., 2013; Nwanna et al., 2019). Therefore, the antioxidant capacity of Chaenomeles fruits, determined in the range from $565.8 \pm 15.7$ (C. speciosa) to $1121.7 \pm 27.5$ ( $C$. cathayensis) mg UAE / $100 \mathrm{~g}$ DW, can be considered quite high. 
According to obtained data, the different biological and nutritional value of henomeles fruits in general and, in particular, their taste qualities depend on the level of their overall antioxidant capacity.

\section{Conclusions}

Thus, a comparative analysis of the fruit and seed capacity of Chaenomeles Lindl. species grown in the botanical garden of the Oles Honchar Dnipro National University was conducted. It's shown that all studied taxa undergo a complete vegetation cycle. Most of the Chaenomeles representatives were found to be in good condition under new growth conditions: the highest vitality was observed in $C$. japonica var. maulei.

The overall antioxidant capacity was highest for $C$. cathayensis fruits (1121.7 $\pm 27.5 \mathrm{mg} \mathrm{AE} \mathrm{/} 100 \mathrm{~g}$ DW), which exceeded the indexes of other species by 1.2-2.0 times. High taste qualities are characteristic of $C$. speciosa and $C$. $\times$ californica. Considering the large assortment of Chaenomeles, representatives differing in their biological, physiological and nutritional properties, we consider it promising to introduce their use in the food industry to obtain functional products with high consumer properties, namely, high content of antioxidants, catering for a variety of dishes or for exotic flavors, as well for direct consumption by the population of useful fruits with different flavors.

\section{References}

Andrusevich, K. V., Nazarenko, M. M., Lykholat, T. Yu., \& Grigoryuk, I. P. (2018). Effect of traditional agriculture technology on communities of soil invertebrates. Ukrainian journal of Ecology, 8(1), 33-40. doi:10.15421/2017_184

Augustus, O., Janet, J., Ebenezer, T., \& Ogboma, U. (2015). Antioxidant Activities, Total Flavonoid and Total Phenolic Contents of Whole Plant of Kyllinga Erecta Shumach. Journal of Food and Nutrition Research, 3(8), 489-494.

Baranovski, B., Khromykh, N., Karmyzova, L., Ivanko, \& Lykholat, Y. (2016). Analysis of the alien flora of Dnipropetrovsk Province. Biological Bulletin of Bogdan Chmelnitskiy Melitopol State Pedagogical University, 6 (3), 419-429.

Beltyukova, S. V., Stepanova, A. A., \& Liventsova, E. O. (2014). Antioksidantyi v pischevyih produktah i metodyi ih opredeleniya. [Antioxidants in food foods and methods of their determination]. Visnik ONU. Himiya, 19, 4(52), 16-30. (in Russian.).

Berger, S., Söhlke, G., Walther, G.-R., \& Pott R. (2007). Bioclimatic limits and range shifts of cold-hardy evergreen broadleaved species at their northern distributional limit in Europe. Phytocoenologia, 37, 523-539.

Crisosto, C. H., Garner, D., Crisosto, G. M., \& Bowerrman, E. (2004). Increasing “Blackamber" plum (Prunus salisina Lindell) consumer acceptance. Postharvest Biology and Technology, 34(3), 237-244. doi: 10.1016/ j.postharvbio.2004.06.003

Deepa, G., Ayesha, S., Nishtha, K., \& Thankamani, M. (2013). Comparative evaluation of various total antioxidant capacity assays applied to phytochemical compounds of Indian culinary spice. International Food Research Journal, 20(4), $1711-1716$.

García-Mariño, N., De la Torre, F., \& Matilla, A. J. (2008). Organic Acids and Soluble Sugars in Edible and Nonedible Parts of Damson Plum (Prunus domestica L. subsp. insititia cV. Syriaca) Fruits During Development and Ripening. Food Science and Technology International, 14(2), 187-193. doi: 10.1177/1082013208092150

Grygoryuk, I. P., Javorovskyj, P. P., \& Lykholat, Yu. V. (2014). Texnolohiji vyroščuvannja i biorehuljacija stijkosti hazonnyx roslyn u miskomu urbanizovanomu seredovyšči: monohrafija [Technology of cultivation and resistance bioregulation of turf grasses plants in urban urbanized environments: monograph]. National University of Bioresources and Nature Management of Ukraine, Kyjiv. (in Ukrainian.).

Homich, G. P., Tkach, N. I., \& Levchenko, Y. V. (2014). Doslidzhennya himichnogo skladu plodiv henomelesu i vikoristannya jogo v sokovomu virobnictvi [Research of chemical composition of garden-stuffs of Chaenomeles and use of him is in exit-juice]. DonNUET, 1(61), 98-104. (in Ukrainian.).

Kaldmae, H., Kikas, A., Arus, L. \& Libek, A. (2013). Genotype and microclimate conditions influence ripening pattern and quality of blackcurrant (Ribes nigrum L.) fruit. Zemdirbyste-Agriculture, 100(2), 167-174. doi: 10.13080/z-a.2013.100.021

Khromykh, N. O., Lykholat, Y. V., Kovalenko, I. M., Kabar, A. M., Didur, O. O., \& Nedzvetska, M. I. (2018). Variability of the antioxidant properties of Berberis fruits depending on the plant species and conditions of habitat. Regulatory Mechanisms in Biosystems, 9(1), 56-61. doi: 10.15421/021807

Kohno, N. A., \& Kurdyuk, A. M. (2010). Teoreticheskie osnovyi i opyit introduktsii drevesnyih rasteniy v Ukraine. [Theoretical bases and experience of introduction of arboreal plants are in Ukraine]. PP Format, Ichnya. 188 p. (in Russian.).

Lykholat, T. Yu., Lykholat, O. A., Marenkov, O. M., Kulbachko, Yu. L., Kovalenko, I. M. \& Didur, O.O. (2019). Xeneostrogenes influence on cholinergic regulation in female rats of different age. Ukrainian Journal of Ecology, 9(1), 240-243. https://www.ujecology.com/articles/xeneostrogenes-influence-on-cholinergic-regulation-in-female-rats-of-different-age.pdf

Lykholat, T. Y., Marenkov, O. M., Yashchenko, K. V., Shaldyna, E. S., \& Lykholat, O. A. (2018). Vplyv syntetychnykh estrogeniv u produktakh kharchuvannya na sistemu detoksykatsii tvaryn riznogo viku [Influence of synthetic ethrogenes in food products on the detoxication system of animal animals of different age]. Scientific Reports of NULES of Ukraine, 2(72). (in Ukrainian.). http://journals.nubip.edu.ua/index.php/Dopovidi/article/view/10635

Lykholat, O. A., Grigoryuk, I. P. \& Lykholat, T. Y. (2016). Metabolic effects of alimentary estrogen in different age animals. Annals of Agrarian Science, 14(4), 335-339. https://doi.org/10.1016/j.aasci.2016.09.012

Lykholat, Y., Khromykh, N., Didur, O., Alexeyeva, A., Lykholat, T., \& Davydov, V. (2018). Modeling the invasiveness of Ulmus pumila in urban ecosystems under climate change. Regulatory Mechanisms in Biosystems, 9(2), 161-166. doi: 10.15421/021824

Lykholat, Yu. V., Khromykh, N. O., Ivan'ko, I. A., Matyukha, V. L., Kravets, S. S., Didur, O. O., Alexeyeva, A. A. \& Shupranova, L. V. (2017). Assessment and prediction of the invasiveness of some alien plants in conditions of climate change in the steppe Dnieper region. Biosystems Diversity, 25(1), 52-59. doi 10.15421/011708 
Marenkov, O., Lykholat, T., Lykholat, O., \& Petrovsky, O. (2019). Level of Edcs in Procambarus virginalis organism at developing stages as potential hazard for water biota and aquatic culture consumers. $3^{\text {rd }}$ International Conference "Smart Bio" (02-04 May 2019). Kaunas, Lithuania, p. 177.

Mezhens'kij, V. M. (2004). Henomeles [Chaenomeles]. Stalker, Donec'k. 62 p.

Myitsyik, L. P., \& Lykholat, Yu. V. (2000). Riven' akumulyatsii vajkyh metaliv u roslynah Poa angustifolia L. u shtuchnyh biogeotsenozah [A level of accumulation of heavy metals is in the plants of Poa of angustifolia L. in artificial geobiocenosiss]. Issues of steppe forestry and forest reclamation of soils, 4, 25-28. (in Ukrainian.)

Nwanna, E. E., Ibukun, E. O., \& Oboh, G. (2013). Inhibitory effects of methanolic extracts of two eggplant species from SouthWestern Nigeria on starch hydrolysing enzymes linked to type-2 diabetes. African Journal of Pharmacy and Pharmacology, 7(23), 1575-1584.

Nwanna, E. E., Ibukun, E. O., \& Oboh, G. (2019). Nutritional content of selected species of tropical eggplant fruit (Solanum $s p p$ ) diet Attenuates hepatic inflammation in high-fat fed male Wistar rats induced with streptozotocin. Food Science \& Nutrition, 7(1), 109-119.

Opanasenko, V. F., Kabar, A. N., Martyinova, N. V., Domnitskaya, I. L., Bilyik, I. V., Lomyiga, L. L., Zamyatina, L. P. (2015). Katalog rasteniy botanicheskogo sada Dnepropetrovskogo natsionalnogo universiteta imeni Olesya Honchara [Catalogue of plants of botanical garden of the Oles Honchar Dnepropetrovsk National University]. Lira, Dnipropetrovsk. 228 p. (in Russian.).

Opanasenko, V. F., Lykholat, Yu. V., Rudnytska, Ye. M., \& Hovorun, I. O. (1998). Bahatorichni kvitkovo-dekoratyvni roslyny dlia ozelenennia promyslovoho mista [Perennial flower and ornamental plants for planting the industrial city]. Industrial botany: the state and prospects of development. Materials of the III International sciences conf. Agency "Multimpress", Donetsk, 277281. (in Ukrainian.).

Pertseva, T. A., Lykholat, E. A., \& Gurzhiy, E. V. (2007). Ocenka sostoyaniya mukociliarnogo klirensa u pacientov s hronicheskim obstruktivnym zabolevaniem lyogkih [The evaluation of mucociliary clearance in patients with chronic obstructive pulmonary disease]. Ukrainian Pulmonology Journal, 3, 16-18. (in Ukrainian.).

Pertseva, T. A., Lykholat, E. A., \& Gurzhiy, E. V. (2008). Vliyanie tiotropiya bromida na sostoyanie mukociliarnogo klirensa u bol'nyh hronicheskim obstruktivnym zabolevaniem legkih. [The influence of tiotropium bromide on mucociliary clearance's condition in patients with chronic obstructive pulmonary disease]. Ukrainian Pulmonology Journal, 1, 13-15. (in Ukrainian.).

Pokhylenko, A. P., Lykholat, O. A., Didur, O. O., Kulbachko, Yu. L., \& Lykholat, T. Yu. (2019). Morphological variability of Rossiulus kessleri (Diplopoda, Julida) from different biotopes within Steppe Zone of Ukraine. Ukrainian Journal of Ecology, 9(1), 176-182. https://www.ujecology.com/articles/morphological-variability-of-rossiulus-kessleri-diplopoda-julida-from-differentbiotopes-within-steppe-zone-of-ukraine.pdf

Pulido, R., Bravo, R., \& Saura-Calixto, F. (2000). Antioxidant activity of dietary polyphenols as determined by a modified ferric reducing/antioxidant power assay. Journal of Agricultural and Food Chemistry, 48, 3396-3402.

Savel'eva, L. S. (1975). Ustojchivost' derev'ev i kustarnikov v zashchitnyh lesnyh nasazhdeniyah [Stability of trees and bushes is in the protective forest planting]. Lesnaya promyshlennost', Moscow. 168 p. (in Russian.)

Savosko, V. M. (2011). Melioraciya ta fitorekultyvaciya zemel [Land melioration and phyreclamation]. Dionis, Kryvyj Rih. (in Ukrainian.).

Savosko, V., Lykholat, Yu., Domshyna, K., \& Lykholat, T. (2018). Ekolohichna ta heolohichna zumovlenist poshyrennia derev i chaharnykiv na devastovanykh zemliakh Kryvorizhzhia [Ecological and geological determination of trees and shrubs' dispersal on the devastated lands at Kryvorizhya]. Journal of Geology, Geography and Geoecology, 27(1), 116-130. (in Ukrainian.). doi:10.15421/111837

Serdyuk, M. Y., \& Stepanenko, D. S. (2015). Formuvannya smakovih yakostey plodiv slivi pid vplivom abiotichnih chinnikiv [Formation of the taste of plum fruits under the influence of abiotic factors]. Eastern-European journal of enterprise technologies, 4, 10(76), 55-60. (in Ukrainian.). doi: 10.15587/1729-4061.2015.46579

Shcherbyna, R. O., Danilchenko, D. M., Parchenko, V. V., Panasenko, O. I., Knysh, E. H., Khromykh, N. O., \& Lykholat, Y. V. (2017). Studying Of 2-((5-R-4-R1-4H-1,2,4-Triazole-3-Yl)Thio)Acetic Acid Salts influence on growth and progress of Blackberries (KIOWA Variety) Propagules. Research Journal of Pharmaceutical, Biological and Chemical Science, 8, $975-979$.

Vinnychenko, O. M., Bil'chuk, V. S., Lykholat, Yu. V., Rossyhina-Galycha, H. S., \& Shupranova, L. V. (2014). Speczpraktykum z fiziologiyi ta biohimiyi roslyn [Special practice on physiology and biochemistry of plants]. FOP Serednyak T. K., Dnipropetrovs'k. 224 p. (in Ukrainian.).

Yermishev, O., Lykholat, O., \& Lykholat, O. (2017). Effect of alimentary synthetic estrogen on cell compensatory mechanisms in rats of different ages. Biologija, 63(2), 152-159.

\section{Citation:}

Y. V. Lykholat, N. O. Khromykh, T. Y. Lykholat, O. O. Didur, O. A. Lykholat, T. V. Legostaeva, A. M. Kabar, T. V. Sklyar, V. M. Savosko, I. M. Kovalenko, V. R. Davydov, Yu. V. Bielyk, K. O. Volyanik, A. V. Onopa, K. A. Dudkina, I. P. Grygoryuk (2019). Industrial characteristics and consumer properties of Chaenomeles Lindl. Fruits. Ukrainian Journal of Ecology, 9(3), 132-137. 